
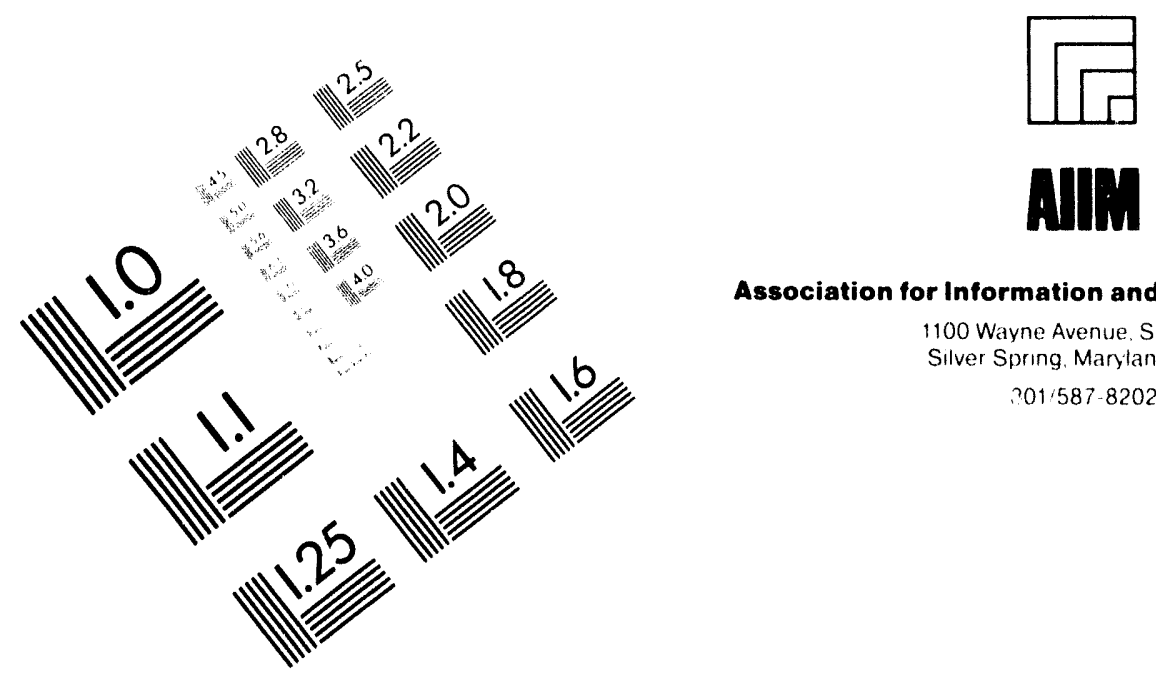

Association for Information and Image Management

1100 Wayne Avenue, Sute 1100

Silver Spring. Maryland 20910

?01/587-8202

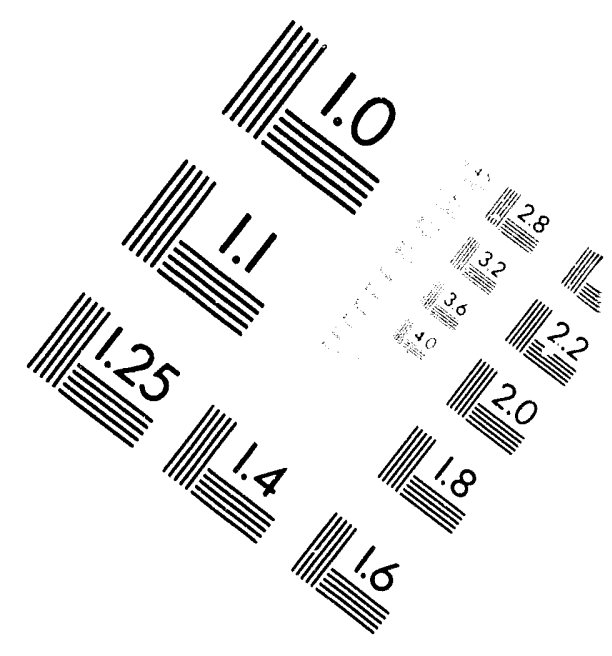

Centimeter

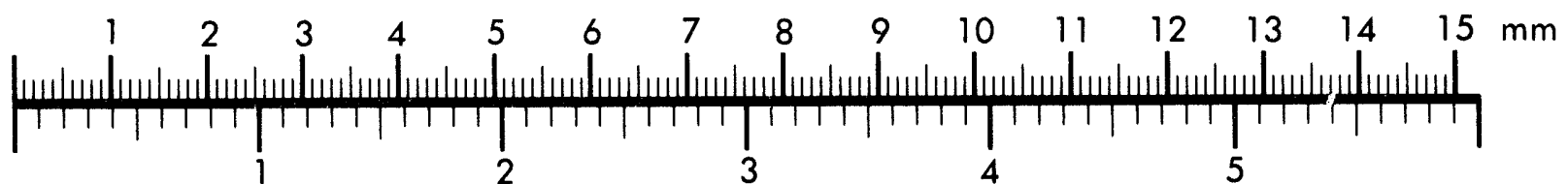
Inches
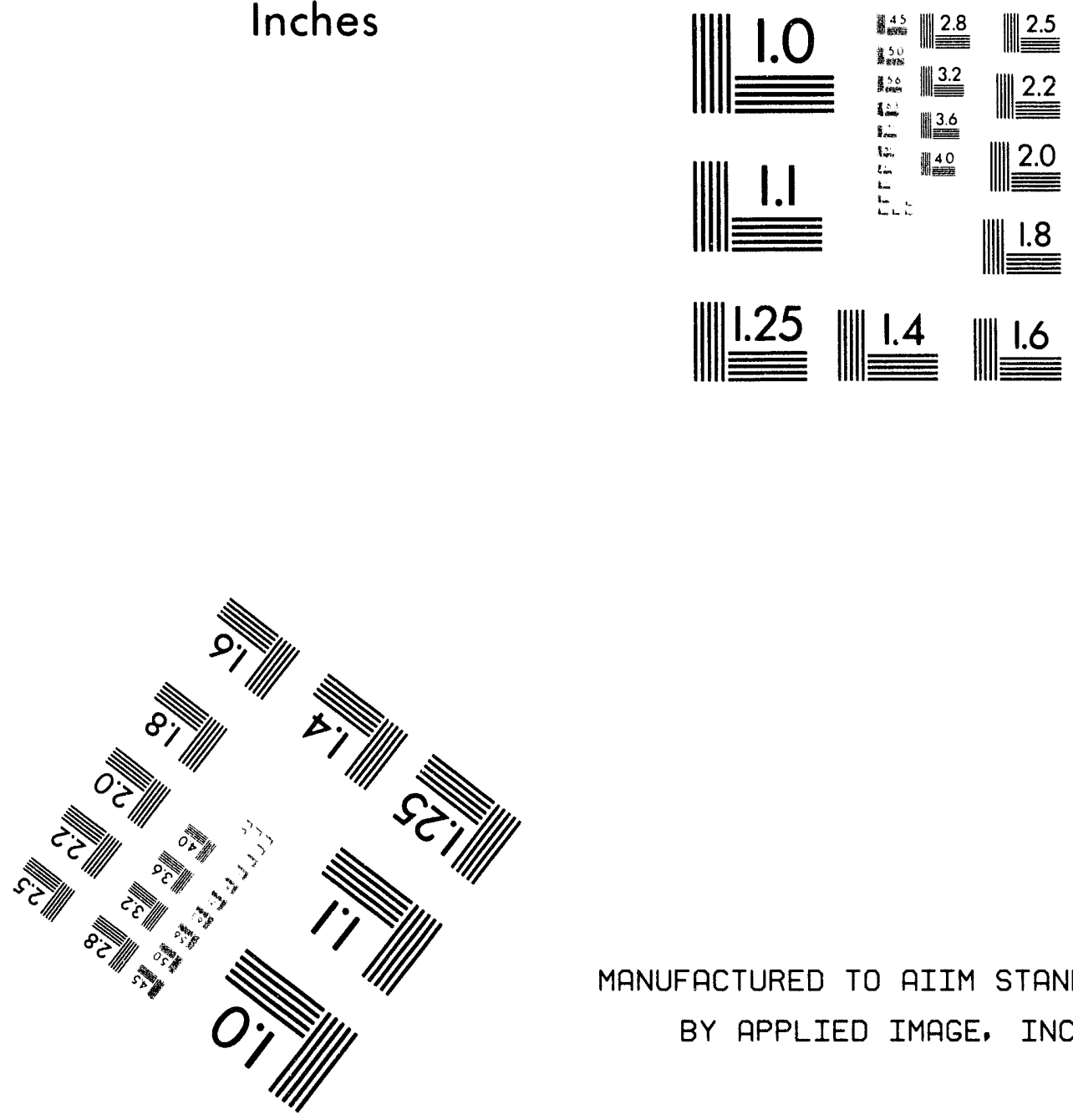

MANUFACTURED TO AIIM STANDARDS BY APPLIED IMAGE, INC.

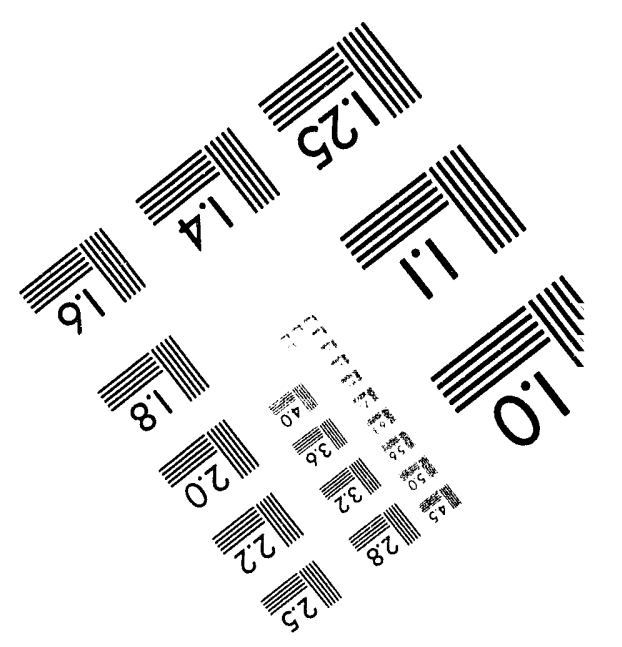



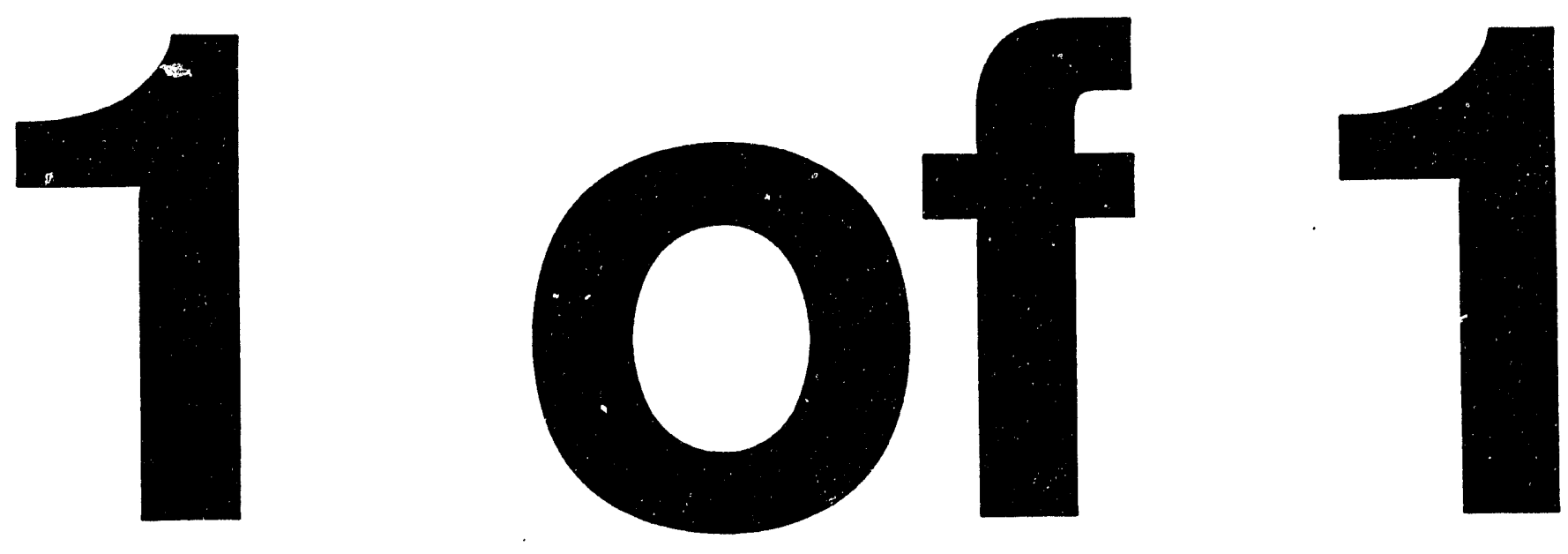


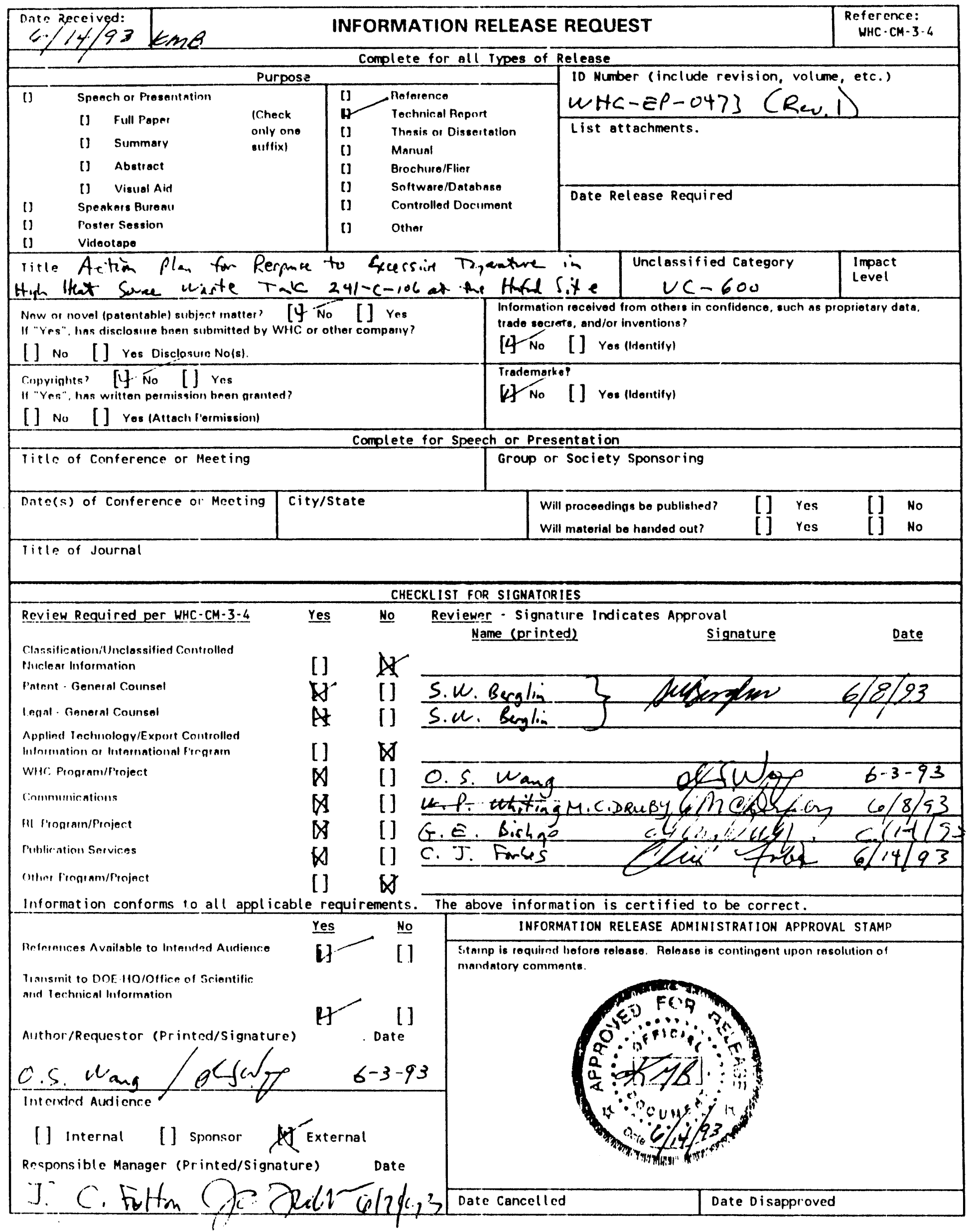


WHC-EP-0473

Revision 1

UC. 600

\title{
Action Plan for Response to Excessive Temperature in High Heat Source Waste Tank 241-C-106 at the Hanford Site
}

\author{
C. DeFigh-Price \\ O. S. Wang
}

Date Published

June 1993

Prepared for the U.S. Department of Energy Office of Environmental Restoration and

Waste Management

\footnotetext{
(2) Westinghouse Hanford Company Richland, Washington 99352

Hanford Operations and Engineering Contractor for the

U.S. Department of Energy Under Contract DE.AC06-87RL10930
} 
WHC-EP-0473, Revision 1

\title{
ACTION PLAN FOR RESPONSE TO EXCESSIVE TEMPERATURE \\ IN HIGH-HEAT SOURCE WASTE TANK 241-C-106 \\ AT THE HANFORD SITE
}

\author{
C. Defigh-Price \\ 0. S. Wang
}

\begin{abstract}
This document defines the actions that will be taken if increasing temperatures, or other conditions that could lead to increased temperatures (such as a leaking tank), are observed in single-shell waste tank 241-C-106 at the Hanford Site. This tank contains a high-heat source (strontium) and requires forced cooling, including water additions. This action plan identifies (1) the criteria and specification limits required for ensuring that tank 241-C-106 is maintained in a safe condition; (2) the responsible organizations for tank 241-C-106; (3) the response actions to prevent or mitigate anomalies; and (4) the immediate and long-term actions that would be necessary if tank 241-C-106 were to leak. The action plan identifies immediate, pre-planned actions that can be used in response to an excessive temperature scenario in waste tank 241-C-106. Other general emergency actions for the 200 Area Tank Farms, such as fires and earthquakes, are described in WHC-CM-4-43, "Emergency Management Procedures".
\end{abstract}


Document Title: Action Plan for Response to Excessive Temperature in High-Heat Source Waste Tank 241-C-106 at the Hanford Site

Approved by:

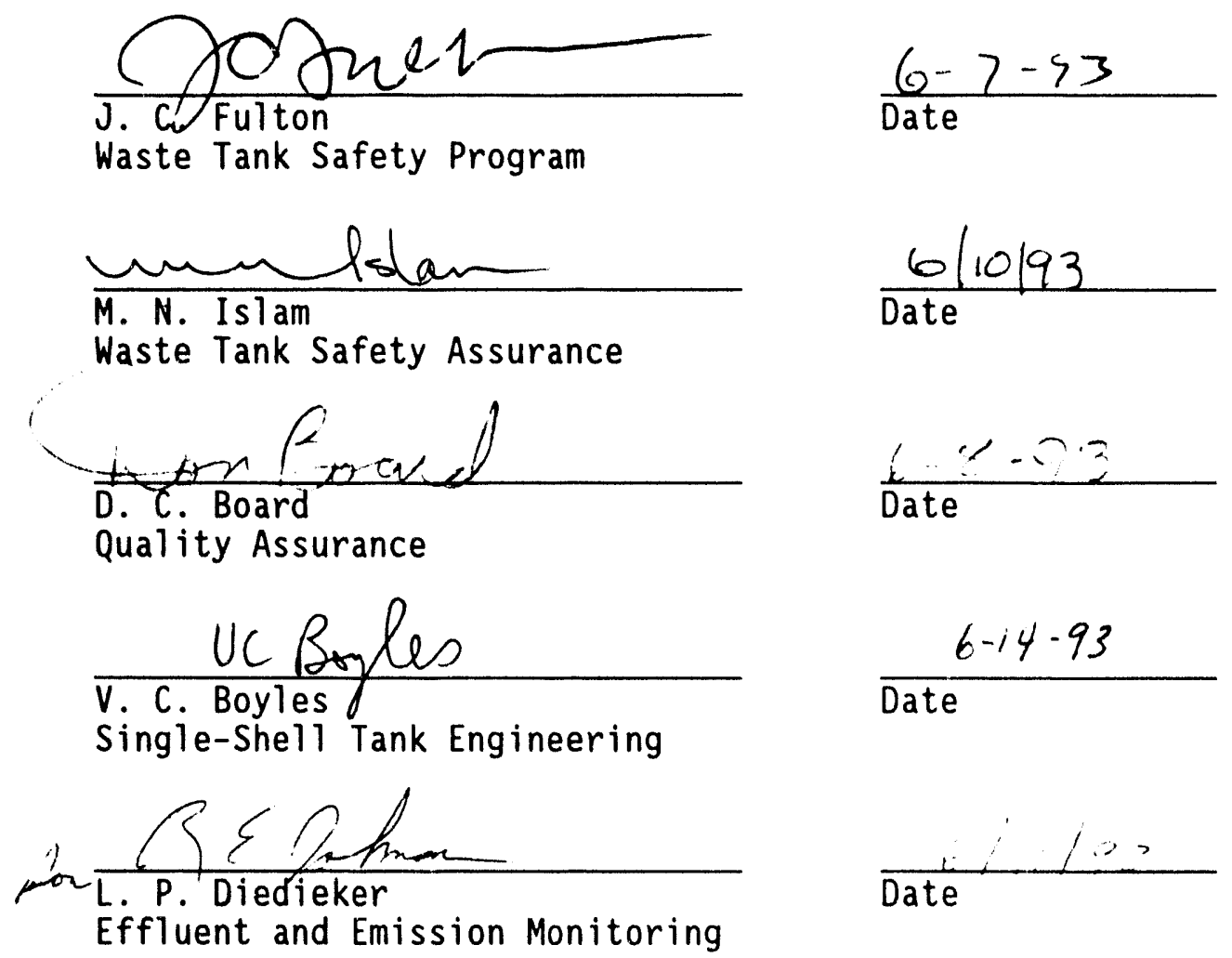


WHC-EP-0473, Revision 1

\section{CONTENTS}

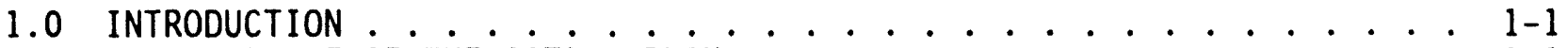

1.1 PURPOSE OF THE ACTION PLAN ............. . . 1-1

1.2 SCOPE OF THE ACTION PLAN ............... . . . . .

2.0 BACKGROUND INTRODUCTION ................ . . 2-1

2.1 BACKGROUND TO THE ACTION PLAN ............ 2- . 2-1

2.2 BACKGROUND TO TANK 241-C-106 ........... 2-2

2.3 PHYSICAL DESCRIPTION OF HANFORD SITE C TANK FARM .... $2-2$

2.4 CURRENT CONFIGURATION OF TANK $241-\mathrm{C}-106 \ldots \ldots . . . . .2-4$

2.4.1 Tank Configuration ............ 2- 2-4

2.4 .2 Instrumentation ............ 2-5

2.4.3 Ventilation............. 2-5

3.0 DISCUSSION . . . . . . . . . . . . . . . . . 3-1

3.1 TEMPERATURE MONITORING AND RESPONSE ........... $3-1$

3.1.1 Administrative Controls . . . . . . . . . . . . 3-1

3.1.2 Tank Temperature Criteria . . . . . . . . . . . 3-1

3.1.3 Monitoring Frequencies . . . . . . . . . . . . . 3-2

3.1.4 Reporting Requirements ............. . 3-2

3.2 AIRBORNE RADIATION-LEVEL MONITORING AND RESPONSE .....

3.2.1 Administrative Controls ........... 3-3

3.2.2 Airborne Radiation-Level Monitoring Criteria . . . . . 3-4

3.2.3 Monitoring Frequencies . . . . . . . . . . . . . 3-4

3.2.4 Reporting Requirements . . . . . . . . . . . . . 3-4

3.3 TANK PRESSURE MONITORING AND RESPONSE . . . . . . . . . 3-5

3.3.1 Administrative Controls . . . . . . . . . . . . . 3-5

3.3.2 Tank Pressure Monitoring Criteria . . . . . . . . 3-5

3.3.3 Monitoring Frequencies............ 3-5

3.3.4 Reporting Requirements . . . . . . . . . . . 3-6

3.4 WASTE TANK LEAK DETECTION AND RESPONSE . . . . . . . . . 3-6

3.4.1 Administrative Controls . . . . . . . . . . . 3-6

3.4.2 Waste Tank Leak-Detection Criteria . . . . . . . . 3-6

3.4.2.1 Waste Tank Liquid-Level Monitoring Criteria . . . 3-6

3.4.2.2 Dry-Well Monitoring Criteria . . . . . . . . . 3-7

3.4.3 Monitoring Frequencies . . . . . . . . . . . 3-7

3.4.3.1 Waste Tank Liquid-Level Monitoring Frequencies . 3-7

3.4.3.2 Dry-Well Monitoring Frequencies . . . . . . . . 3-7

3.4.4 Reporting Requirements . . . . . . . . . . . . 3-7

3.5 Waste Tank Forced Ventilation Failure and Response . . . . . 3-7

3.5.1 Administrative Controls . . . . . . . . . . . 3-9

3.5.2 Monitoring Requirements . . . . . . . . . . . . . . 3-9

3.5.3 Reporting Requirements . . . . . . . . . . 3-9

4.0 RESPONSIBILITIES . . . . . . . . . . . . . . . . 4-1

5.0 CORRECTIVE ACTIONS ................. . . . . .

5.1 TEMPERATURE INCREASES ................ 5 . . 
WHC-EP-0473, Revision 1

\section{CONTENTS (Continued)}

5.2 LEAKING TANK . . . . . . . . . . . . . . . . . . . 5-1 5.2.1 Immediate Actions ............... . 5-1 5.2.2 Long-Term Actions .. . . . . . . . . . . . . . . . . . 5-2

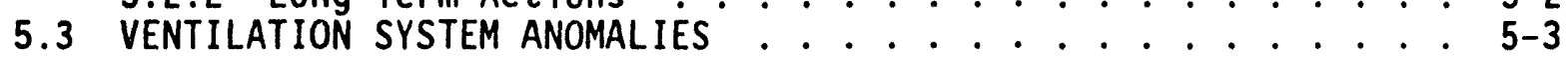

6.0 REFERENCES .......................... . . 6-1

\section{LIST OF FIGURES}

2-1 Diagram of Single-Shell 530,000-gallon Tanks

in Hanford Site C Tank Farm . . . . . . . . . . . . . . . 2-3

2-2 Riser Locations for Tank 241-C-106 . . . . . . . . . . . . . . 2-6

3-1 Temperature Curve for Tank 241-C-106

from January 1990 to October 1992 . . . . . . . . . . . . . . 3-8

5-1 Sprinkler System Model . . . . . . . . . . . . . . . . . . 5-4

\section{LIST OF TABLES}

2-1 SST With High-Heat Content . . . . . . . . . . . . . . 2-1 
WHC-EP-0473, Revision 1

\section{ACTION PLAN FOR RESPONSE TO EXCESSIVE TEMPERATURE \\ IN HIGH-HEAT SOURCE WASTE TANK 241-C-106}

AT THE HANFORD SITE

\subsection{INTRODUCTION}

\subsection{PURPOSE OF THE ACTION PLAN}

This action plan identifies the responses that shall be implemented if anomalies in temperature measurements, or conditions that could lead to temperature anomalies (such as a leaking tank), are observed in tank 241-C-106 of the Hanford Site C Tank Farm. This plan also summarizes (1) the criteria and specification limits required for ensuring that tank $241-C-106$ is maintained in a safe condition; (2) the responsible organizations for tank 241-C-106; and (3) response actions to prevent or mitigate safety concerns. The main safety concern unique to tank $241-C-106$ is the temperature rise due to heat generation by the waste content.

\subsection{SCOPE OF THE ACTION PLAN}

The information contained in this action plan applies specifically to tank 241-C-106. Other general emergency actions are described in the Westinghouse Hanford Company (WHC) Emergency Management Procedures (WHC-CM-4-43), as required by the Westinghouse Hanford Company Emergency Plan (WHC-CM-4-1). This action plan is administered and controlled locally specifically for tank 241-C-106. However, if a developing event may impact a larger area, or even affect the public, emergency actions provided by WHC-CM-4-1 and WHC-CM-4-43 shall be followed as appropriate. WHC-CM-4-1 contains an emergency preparedness plan in compliance with applicable DOE Orders and WHC policies to protect onsite personnel, public health and safety, and the environment in the event of operational, natural phenomena, and/or safeguards and security events at WHC facilities. WHC-CM-4-43 provides more specific emergency management procedures for key WHC facilities and procedural steps in an emergency, such as notification, activation of the Emergency Management Center, event command, recovery actions, etc. A specific emergency response plan in response to a fire or explosion event is addressed in WHC-SD-PRP-TI-001 (Marsh 1991). The interface of these plans and procedures depends on the type and degree of a developing accident, and the extent of the potentially affected area.

In accordance with the requirements of Public Law 101-510, Section 3137, this action plan identifies the responses that would be taken to correct excessive temperature rises, or conditions that could lead to temperature rises (such as a tank leak or the failure of the forced cooling system) if not corrected for tank 241-C-106. This action plan also identifies the conditions under which corrective action responses shall be initiated. All the reporting requirements are described in Section 3.0 in accordance with WHC-CM-5-5, "Waste Tank Anomaly Analys is and Reporting," and WHC-CM-7-5, "Environmental Compli ance." 
The requirement of Public Law 101-510 to respond to excessive pressure is not relevant to the high-heat issue, because the excessive pressure failure mode is structural degradation (which is not potentially explosive in nature). Pressure in the tank ventilation system is monitored in accordance with OSD-T-151-0013 (WHC 1992a).

This action plan does not include the requirement of Public Law 101-510 for a response to a release of radioactive material from tank 241-C-106. The response to possible accidents that may result in a release at the Hanford Site are addressed in the Westinghouse Hanford Company Emergency Plan (WHC-CM-4-1), Westinghouse Hanford Company Emergency Management Procedures (WHC-CM-4-43), and the Tank Farm Stabilization Plan for Emergency Response (Marsh 1991). A leak to the soil column from tank 241-C-106 would be one condition that could lead to a temperature increase due to a loss of cooling water. The failure of existing forced ventilation cooling system is a second condition. A release of radioactive material from tank 241-C-106 ventilation system could indicate that an anomalous situation has occurred in the ventilation system, which also requires corrective action. Cessation of water addition is another condition that could lead to excessive temperature. 


\subsection{BACKGROUND INTRODUCTION}

\subsection{BACKGROUND TO THE ACTION PLAN}

Subsection (b) of Public Law 101-510, Section 3137, "Safety Measures for Waste Tanks at Hanford Nuclear Reservation" (PL 101-510), requires the Secretary of Energy to take the following actions with regard to any Hanford Site single-shell tank (SST) or double-shell tank (DST) that has been identified, under Subsection (a) of the law, as having a serious potential for release of high-level waste:

- Identify those tanks that "may have a serious potential for release of high-level waste due to uncontrolled increases in temperature or pressure..."

- Ensure that "continuous monitoring to detect a release or excessive temperature pressure..." is being carried out

- Develop "action plans to respond to excessive temperature or pressure or a release from any tank identified..."

- Restrict additions of high-level nuclear wastes to the identified tanks unless no safer alternative exists or the serious potential for a release of high-level nuclear waste is no longer a threat.

These tanks have been identified pursuant to Subsection (a), and are categorized by tank contents (Wilson and Reep 1991). Categories include those tanks that (1) have the potential for flammable gas generation; (2) contain ferrocyanide compounds; (3) contain organics; or (4) have high-heat loads. The high-heat load category (Table 2-1) includes one tank of concern: SST 241-C-106. This action plan specifically addresses the high-heat load of SST $241-C-106$.

Table 2-1. SST W: th High-Heat Content.

\begin{tabular}{|c|c|c|c|c|c|}
\hline \multirow{2}{*}{$\begin{array}{c}\text { Tank } \\
\text { number }\end{array}$} & \multicolumn{2}{|c|}{$\begin{array}{c}\text { Environmental } \\
\text { monitoring }\end{array}$} & \multicolumn{2}{c|}{$\begin{array}{c}\text { Temperature } \\
\text { monitoring }\end{array}$} & $\begin{array}{c}\text { Dome space } \\
\text { pressure } \\
\text { monitoring }\end{array}$ \\
\cline { 2 - 5 } & Tank & Area & Type & Frequency & \\
\hline SST 241-C-106 & CM & CM & TC & Weekly & No $^{*}$ \\
\hline
\end{tabular}

$C M=$ continuous monitoring of radiation detector.

$T C=$ thermocouple tree.

"Tank is ventilated with exhaust fans, and ventilation duct pressures are monitored. 


\subsection{BACKGROUND TO TANK 241-C-106}

Tank $241-C-106$ is a $2,000-\mathrm{m}^{3}(530,000-$ gal) capacity SST located in the Hanford Site C Tank Farm (Figure 2-1). The C Tank Farm is one of the four original tank farms ( $B, C, T$, and $U)$ that were constructed at the Hanford Site 200 areas during 1944 and 1945. Tank 241-C-106 has been used for radioactive waste storage since mid-1947.

During the late 1960s, a program to recover strontium and cesium from aging waste stored in the $A$ and $A X$ Tank Farms was instituted at the Hanford Site. A sludge washing/decanting process took place in the 244-AR vault, requiring the washing of accumulated slurry with water to remove soluble constituents. The original intent was to decant the wash solution [Plutonium-Uranium Extraction (PUREX) sludge supernate] from the solids by settling the solids and then pumping off the supernate (the liquid portion of a solid-liquid separation process) to tank 241-C-106. The decanting step proved to be ineffective, however, and strontium solids were drawn into and transferred with the wash solution to tank 241-C-106, where they accumulated.

By mid-1971, it became obvious that unacceptable quantities of strontium had been transferred with the PUREX sludge supernate when temperatures in excess of $100^{\circ} \mathrm{C}\left(212^{\circ} \mathrm{F}\right)$ were observed in tank 241-C-106. Because the tanks in the C Farm were not equipped for the storage of self-boiling waste, transfers of PUREX sludge supernate to tank 241-C-106 were halted, and tank 241-C-106 was immediately placed on an active ventilation system. Since mid-1971 water has been added periodicaliy to the tank, in order to keep the sludge wet and to promote heat transfer. Tank 241-C-106 was placed on inactive status in 1979, and is currently categorized as sound (i.e., not leaking).

Based on the conclusions of a stabilization evaluation of tank 241-C-106 (Pauley and Torgerson 1987), it was concluded that tank 241-C-106 could not be cooled solely by forced-air cooling until approximately the year 2045 (when the radioactive strontium would sufficiently decay). Cooling water (approximately 10,000 gal/month) is presently being added to tank 241-C-106, and will continue to be added until alternate cooling methods are approved or until sufficient sludge material is removed to negate the need for forced cooling (Welty 1988).

\subsection{PHYSICAL DESCRIPTION OF HANFORD SITE C TANK FARM}

As noted in Section 2.2, the Hanford Site C Tank Farm is one of the original four Hanford Site tank farms ( $B, C, T$, and $U$ ). The $C$ Tank Farm consists of four $210-\mathrm{m}^{3}(55,000-\mathrm{gal})$ tanks and twelve $2,000-\mathrm{m}^{3}(530,000-\mathrm{gal})$ tanks. The $2,000-\mathrm{m}^{3}(530,000-\mathrm{gal})$ tanks are constructed of reinforced concrete with welded carbon steel liners on the bottom and sides. Each tank has a $0.3-m(1-f t)$ dished bottom and a usable waste depth of approximately $4.9 \mathrm{~m}(16 \mathrm{ft})$ at the sidewall. The bottom of each tank consists of a $0.15-m(6-i n$.$) layer of reinforced concrete that is covered with a$ $5-\mathrm{cm}(2-i n$.$) layer of grout and a 1-\mathrm{cm}(3 / 8-i n$.$) steel plate liner. The$ knuckle (transition section from bottom to sidewall) is $1-\mathrm{cm}(3 / 8$-in.) steel plate. The tank sides are $0.33-m-(13-i n .-)$ thick reinforced concrete. 
WHC-EP-0473, Revision 1

Figure 2-1. Diagram of Single-Shell 530,000-gallon Tanks in Hanford Site C Tank Farm.

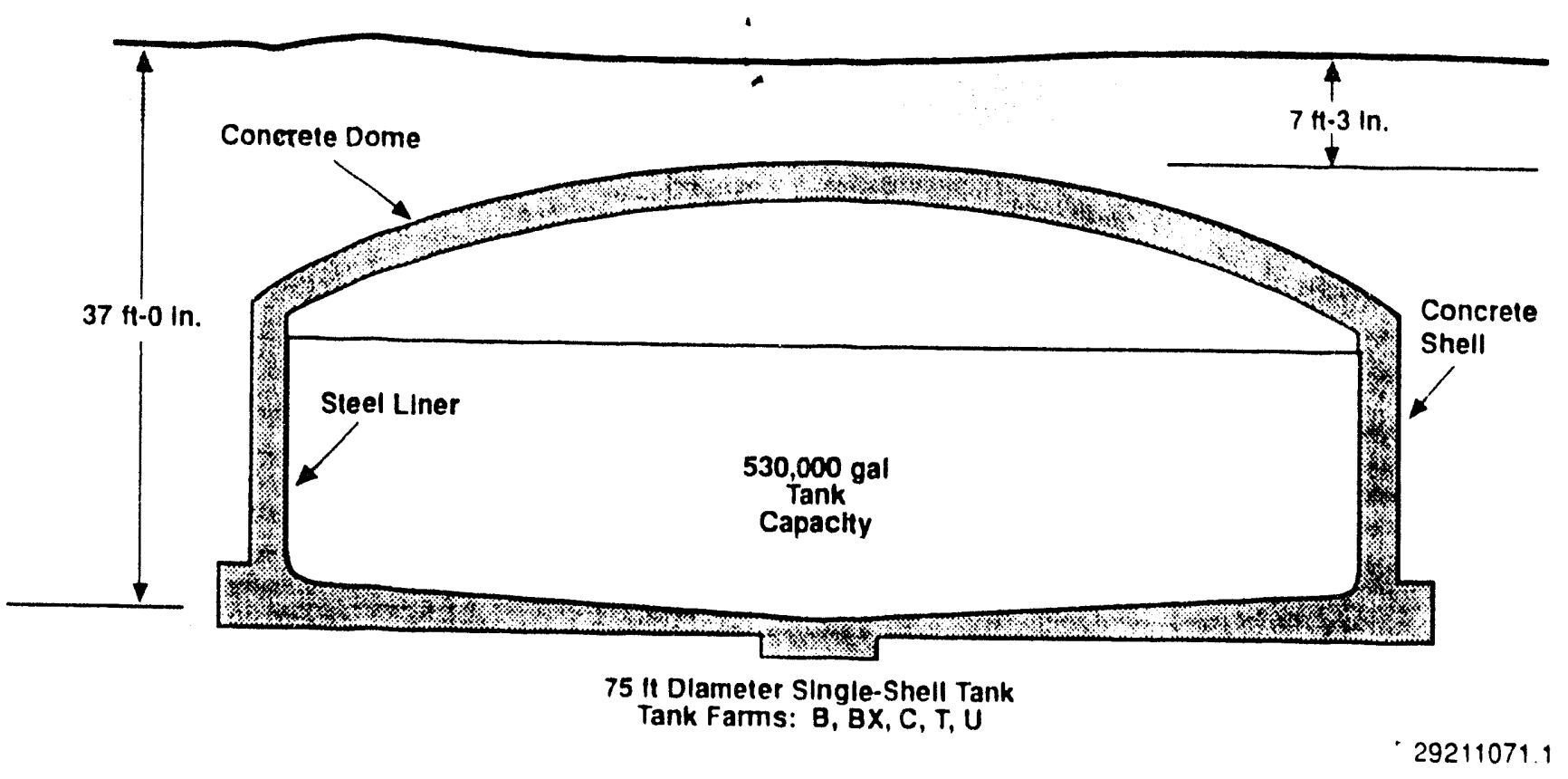


WHC-EP-0473, Revision 1

The steel liner extends $5.5 \mathrm{~m}(18 \mathrm{ft})$ up the straight side of the tank, varying in thickness from 0.6 to $1 \mathrm{~cm}(1 / 4$ to $3 / 8 \mathrm{in}$.) The top of the stee 1 liner is covered with lead flashing to prevent moisture from entering between the liner and concrete wall. The dome is constructed of $0.4-m-(15-i n .-)$ thick reinforced concrete. The tanks were constructed with five $0.1-m$ (4-in.) risers, five $0.3-\mathrm{m}(12-\mathrm{in}$.$) risers, a condenser hatchway connected to the$ tank by a $0.3-m$ (12-in.) duct, and two $1.1-m$ (42-in.) manholes (see drawings $\mathrm{H}-2-37006$ and $\mathrm{H}-2-70496$ through $\mathrm{H}-2-70504)$.

\subsection{CURRENT CONFIGURATION OF TANK 241-C-106}

\subsubsection{Tank Configuration}

Tark 241-C-106 is currently inactive, partially isolated, and actively ventilated. Partial isolation prevents the introduction of any additional material into the tank (except for cooling water additions, which are made to facilitate evaporative cooling). Partial isolation measures on this tank include the following: (1) all pits are weather covered with urethane foam to minimize moisture intrusion; (2) air and water lines to the pits have been cut and sealed; and (3) all process lines to the tank and pits are capperi cr sealed in the CR-153 and $C-151$ diversion boxes. Starting in FY 93, some, of the isolation work, especially the weather covers, will be removed or wodified in preparation of sludge removal.

These measures have been taken to comply with the requirements of U.S. Department of Energy (DOE) Field Office, Richland (RL), Order 5820.2A, which prohibits the addition of any liquid to SSTs for the purpose of storage (DOE-RL 1990). The tank is only partially isolated, since cooling water is added to the tank (as allowed by DOE-RL 1990). The pump pit stili contains the jumpers and pump used to remove material from the tank, and the sluice pit still contains the jumpers and drop legs used to add material to the tanks.

In 1987, the sludge heat-generation rate for tank 241-C-106 was estimated to be between 61,550 to $176,000 \mathrm{Btu} / \mathrm{h}$, with a most likely rate being

approximately 158,000 Btu/h (Pauley and Torgerson 1987). The most significant heat-producing isotope in the tank is strontium, and the heat-generation rate of the sludge is expected to decline with time in correspondence to the 28.1-yr half-life of strontium.

Water additions to tank 241-C-106 are made approximately every 4 to 8 weeks. Water is added from a tank truck through the pump pit drain. To keep the sludge wet and to facilitate evaporative cooling, the supernate liquid layer above the sludge is controlled between 2.0 and $1.9 \mathrm{~m} \mathrm{(79}$ and $74.5 \mathrm{in}$. levels). Water additions average about 7,000 to $10,000 \mathrm{gal} . / \mathrm{month}$. When the liquid level is close to the minimum level, water is added to raise it to the maximum level. If a leak were to occur, present forced cooling techniques would mean that (1) water would be needed to replace the water that is lost through evaporation; and (2) water would have to be added to the tank to offset the amount being lost by the leak until remediation actions could be taken (Welty 1988). 
WHC-EP-0473, Revision 1

\subsubsection{Instrumentation}

Instrumentation for tank $241-C-106$ consists of a Food Instrument Corporation liquid-level gage mounted in riser Rl, two thermocouple trees mounted in risers R8 and R14, and a tank pressure/vacuum gage mounted on riser R7 (Figure 2-2). The Food Instrument Corporation gage transmits liquid-level measurements to the Computer Automated Surveillance System (a continuously monitored computer system) and to the Surveillance Analysis Computer System (an off-line database and data analysis system). The temperatures and tank pressure/vacuum must be read locally at the tank. There are only four thermocouples from either tree that are immersed in the sludge. The waste temperature is approximately $80^{\circ} \mathrm{C}\left(175^{\circ} \mathrm{F}\right)$, which is well below the Operational Safety Document temperature of $150^{\circ} \mathrm{C}\left(300^{\circ} \mathrm{F}\right)$ (WHC 1992a). The $300^{\circ} \mathrm{F}$ temperature requirement is less than the operational safety requirements (OSR) limits of $350^{\circ} \mathrm{F}$ (Smith 1986b).

Six dry wells are associated with tank 241-C-106. These dry wells are vertical steel casings in the ground that range in depth from approximately 30 to $40 \mathrm{~m}$ ( 100 to $130 \mathrm{ft}$ ). Gamma and neutron detection probes are lowered into these wells to monitor for possible leaks through an increase in radiation profiles (gamma detector) or moisture levels (neutron probes). The radiation scan data in all six of these dry wells around tank 241-C-106 are normal to date. The readings have remained consistent with the reference baselines established for these wells in 1975.

\subsubsection{Ventilation}

The exhauster used to ventilate tank 241-C-106 has been changed several times since the tank was placed on an active ventilacion system. The tank is currently ventilated by the 296-P-16 exhauster. The $20-\mathrm{o}-16$ exhauster is a portable unit of nominal $3 \mathrm{~m}^{3} / \mathrm{s}\left(7,000 \mathrm{ft}^{3} / \mathrm{min}\right)$ capacity. Nominal exhaust flow rates are $0.57 \mathrm{~m}^{3} / \mathrm{s}\left(1,200 \mathrm{ft}^{3} / \mathrm{min}\right)$ and $1.1 \mathrm{~m}^{3} / \mathrm{s}\left(2,400 \mathrm{ft}^{3} / \mathrm{min}\right)$ from tanks 241-C-105 and -106 , respectively.

Air is drawn into the tanks through inlets equipped with high-efficiency particulate air filters. The exhaust air is passed through a deentrainment section (to remove entrained water), and then through a bank of high-efficiency particulate air filters. Deentrained moisture drains back to riser R2 on tank 241-C-106. 
Figure 2-2. Riser Locations for Tank 241-C-106.

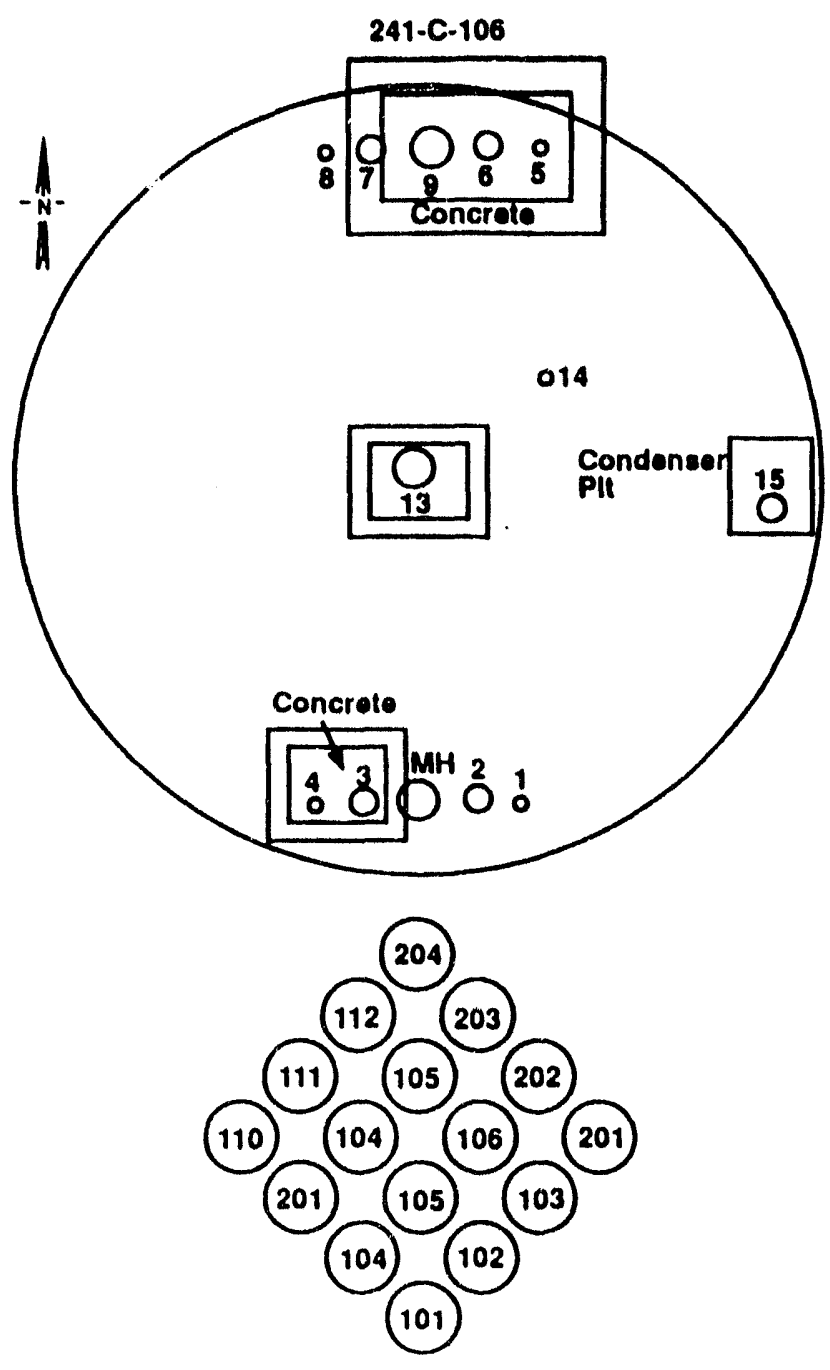

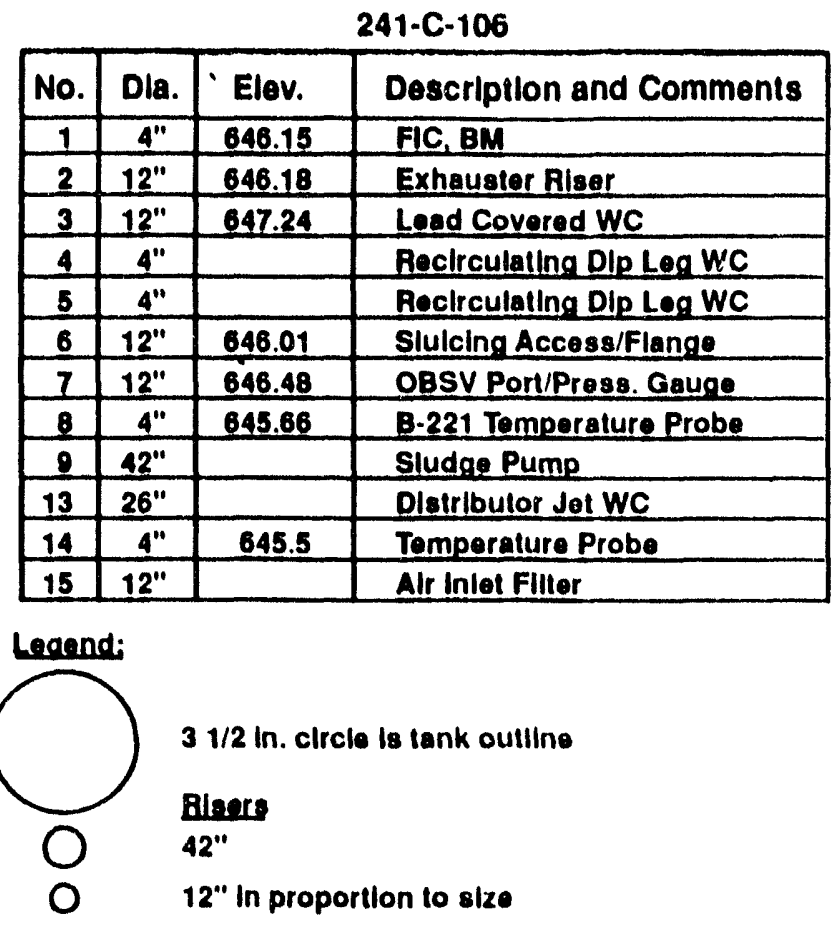

04

$1,2,3$, etc. Riser number - may not agree with fleld ID

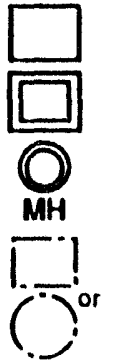

Varlous size rectangles ar plts - may have label

Double rectangle Indicates weather covered plt unless other wise Identilled.

Calseon (USU 72" dla.) - covered

A 42" manhole at dome top - no riser to surlace

Coment pad with a plate (rise is under plate) 


\subsection{DISCUSSION}

\subsection{TEMPERATURE MONITORING AND RESPONSE}

\subsubsection{Administrative Controls}

Administrative documents and procedures are in place to ensure proper responses to anomalous situations in tank 241-C-106. These documents and procedures are as follows:

- Safety analysis reports, which are the primary administrative control documents for SSTs, including tank 241-C-106 (Smith 1986a; Smith 1986b; Boyles 1989).

- Westinghouse Hanford Management Requirements and Procedures, WHC-CM-1-3 (WHC-CM-1-3), Radiation Protection (WHC-CM-4-10), WHC-Emergency Plan (WHC-CM-4-1), Waste Tank Project Administration (Ellis 1992), and Operations-General Administration (WHC-CM-5-5), which implement administrative and technical controls derived from DOE directives.

- Operating Specifications for Single-Shell Waste Storage Tanks (WHC 1992a), and Operating Specifications for Watch List Tanks (WHC 1992b), which establish or detail SST surveillance limits, including those for tank 241-C-106.

- The Waste Storage Tank Status and Leak Detection Criteria (Welty and Vermeulen 1991), which contains specific SST technical criteria limits and controls, including those for tank 241-C-106.

- Procedures for occurrence reporting and processing of operations information (WHC-CM-1-3, MRP 5.14), which specify occurrence reporting system requirements.

- DOE Orders 5484.1, 5481.1B, 5480.1B, 6430.1A, 5820.2A, 5700.6C, 5480.23 , which provide overall administrative guidance.

Criteria and response actions specific only to tank 241-C-106 are listed in this action plan.

\subsubsection{Tank Temperature Criteria}

Tank 241-C-106 will be monitored to determine if an increasing temperature trend exists from the established baseline. Waste temperature in tank 241-C-106 is a key safety control parameter. 
Temperature criteria are specified in the Operating Specifications Document (OSD) Operating Specifications for Single-Shell Waste Storage Tanks, OSD-T-151-00013 (WHC 1992a). These limits are as follows.

- Temperature

1. The temperature of the waste shall not exceed $150^{\circ} \mathrm{C}\left(300^{\circ} \mathrm{F}\right)$.

2. The temperature of the tank dome shall not exceed $120{ }^{\circ} \mathrm{C}$ $\left(250^{\circ} \mathrm{F}\right)$.

3. The maximum temperature change shall be $10^{\circ} \mathrm{C}\left(20^{\circ} \mathrm{F}\right)$ per day.

- Thermocouple trees

Thermocouple trees shall be installed in any SST containing a demonstrated heat load of greater than $12 \mathrm{~kW}(40,000 \mathrm{Btu} / \mathrm{h})$. If two or more probes on a thermocouple tree fail, operability shall be restored as soon as practical. Tank 241-C-106 has one operable TC tree. The second TC tree is scheduled for repair in FY 93.

\subsubsection{Monitoring Frequencies}

The Safety Analysis Report (Smith 1986b) concluded that heat loads less than $40,000 \mathrm{Btu} / \mathrm{h}$ would not result in waste temperatures greater than $350{ }^{\circ} \mathrm{F}$. This could prevent the stress corrosion cracking that could result in tank failure. The OSD (WHC 1992a) further lowered the operational limit to $300^{\circ} \mathrm{F}$, with a $50{ }^{\circ} \mathrm{F}$ safety margin.

Sludge temperature readings, in accordance with operating procedures, are recorded at least weekly for tank 241-C-106. The Waste Storage Tank Status and Leak Detection Criteria (Welty and Vermeulen 1991) currently requires that sludge temperature readings be recorded at least once every 38 days.

The temperature change criterion $\left[10^{\circ} \mathrm{C}\left(20^{\circ} \mathrm{F}\right)\right.$ per day $]$ is intended to prevent structural damage. The criterion is satisfied due to the large thermal inertia of the waste. Thermal studies (Jimenez 1991) have indicated that the expected change per day, should forced cooling be stopped, would be considerably less than the criteria limit. This slow heat up rate was confirmed in FY 1992, during a period when the forced cooling was inoperable.

\subsubsection{Reporting Requirements}

The following reporting requirements are specified in The Waste storage Tank Status and Leak Detection Criteria (Welty and Vermeulen 1991).

- Failure to monitor a high-heat load tank within the prescribed frequency is an OSD violation. In this event an occurrence report will be prepared by Administrative Support and issued by Tank Farm Facility Operations in accordance with applicable procedures (WHC-CM-5-5). 
- Exceeding the maximum criterion of $150{ }^{\circ} \mathrm{C}\left(300^{\circ} \mathrm{F}\right)$ is an OSD violation. In this event an occurrence report will be prepared by Administrative Support and issued by Tank Farm Facility Operations in accordance with applicable procedures (WHC-CM-1-3 and WHC-CM-5-5).

- When two or more thermocouples on the same thermocouple tree fail, an OSD violation will result if operability is not restored within 3 months. In this event, an occurrence report will be prepared by Administrative Support and issued by Tank Farm Facility Operations in accordance with applicable procedures (WHC-CM-1-3 and WHC-CM-5-5).

- Waste temperatures shall be monitored in tanks containing waste with a heat load of greater than $40,000 \mathrm{Btu} / \mathrm{h}$. Temperature data shall be analyzed at least quarterly to determine any increasing waste temperature trends (Smith 1986b).

- Other surveillance anomalies [e.g., an anomaly in data that has not exceeded any other criteria (Welty and Vermeulen 1991), such as temperature] that are inconsistent with the historical norm of the tank will result in a discrepancy report being generated by Tank Farm Surveillance Analys is (Ellis 1992). Other anomalies may also result in the issuance of a discrepancy report.

- The system for reporting non-routine releases from WHC facilities is outlined in WHC-CM-7-5, and summarized in Sections 3.2.4 and 3.4.4 of this report.

\subsection{AIRBORNE RADIATION-LEVEL MONITORING AND RESPONSE}

In the context of this action plan, airborne radiation levels relate directly to the performance of the ventilation system for tank 241-C-106, which is an important element in maintaining tank 241-C-106 temperatures within normal conditions.

\subsubsection{Administrative Controls}

Administrative documents and procedures are in place to ensure that corrective responses take $\mathrm{place}$ before any airborne radiation-level readings exceed the criteria in Section 3.2.2. The documents and procedures are presented in Section 3.1.1, with the following addition:

- Emergency responses and reporting guidelines are specified in the Environmental Compliance Manual (WHC-CM-7-5)

- Radiation protection control standards, requirements, and guidelines are specified in the Radiation Protection Manual (WHC-CM-4-10). 
Should additional radiation monituring systems be added to the tank, this action plan will be revised to reflect changes in configuration, criteria, and controls.

\subsubsection{Airborne Radiation-Level Monitoring Criteria}

Airborne radiation-level criteria are specified in the Radiation Protection Manual (WHC-CM-4-10). Gaseous effluent concentrations are specified for annual and weekly averages; instantaneous concentrations are measured at the exhaust stack (WHC 1990). Airborne radiation-level criteria are as follows:

- The annual average concentration of radionuclides released to the environment in airborne effluents shall not exceed the derived concentration guides specified $\vdots n$ Appendix $A$ of the Environmental Compliance Manual (WHC-CM-7-5).

- The weekly average concentration of radionuclides released to the environment in airborne effluents shall not exceed four times the derived concentration guides specified in Appendix A of the Environmental Compliance Manual (WHC-CM-7-5).

- The maximum instantaneous concentration of radionuclides released to the environment in airborne effluents shall not exceed 5,000 times the derived concentration guides specified in Appendix A of the Environmental Compliance Manual (WHC-CM-7-5).

\subsubsection{Monitoring Frequencies}

A continuous air monitor with an alarm capability is located on the 296-P.-16 exhauster stack. Monitors and alarms for all active exhaust stacks shall be functionally tested on a monthly frequency that shall not exceed 45 days (WHC 1990).

\subsubsection{Reporting Requirements}

WHC discrepancy and occurrence reporting requirements are applicable to unexpected increases in airborne radiation levels (Ellis 1992 and WHC-CM-1-3).

Non-routine releases are reported to DOE and WHC environmental personnel in compliance with the Occurrence Reporting and Processing of Operations Information, MRP 5.14 (WHC-CM-1-3), and DOE Order 5000.3A. If a "reportable" release is confirmed per DOE Order 5000.3A, procedure requirements to not ify the National Response Center and Ecology are outlined in WHC-CM-7-5. 
WHC-EP-0473, Revision 1

\subsection{TANK PRESSURE MONITORING AND RESPONSE}

Tank pressure monitoring for tank 241-C-106 is performed only as it relates to performance of the ventilation system. This is an important element in maintaining temperatures within normal conditions.

\subsubsection{Administrative Controls}

Administrative documents and procedures are in $p l a c e$ to ensure that corrective responses take place before any tank pressure readings exceed the criteria in Section 3.3.2. The documents and procedures are identified in Section 3.1.1.

Should additional tank pressure monitoring systems be added to the waste tank, this action plan will be revised to reflect changes in configuration, criteria, and controls.

\subsubsection{Tank Pressure Monitoring Criteria}

Applicable tank pressure criteria are specified in the safety analysis reports (Smith 1986a, 1986b; Boyles 1989), which are the primary administrative control documents for SSTs, including tank 241-C-106.

Specific operating parameters are listed in the Operating Specifications Document (WHC 1992a). These requirements include the following:

- Ventilation operating pressure

Maximum operating pressure of between -0.1 and -5.9 in. water, gage (wg)

- HEPA filter differential pressure

$\begin{array}{ll}\text { First filter in a series } & 0.05 \mathrm{in} \text {. wg to } 5.9 \mathrm{in.wg} \\ \text { Other filter in a series } & 0.05 \mathrm{in} \text {. wg to } 4.0 \mathrm{in} \text {. wg } \\ \text { Total series of filters } & 0.05 \mathrm{in} . w g \text { to } 5.9 \mathrm{in} . \mathrm{wg}\end{array}$

\subsubsection{Monitoring Frequencies}

The waste tank shall have tank pressures monitored on a daily basis that shall not exceed $30 \mathrm{~h}$ between readings (Smith 1986a). The ventilation system (including vacuum in the tank and pressure drop across the HEPA filters) is checked each eight-hour shift, and operational data are logged daily. 
WHC-EP-0473, Revision 1

\subsubsection{Reporting Requirements}

Discrepancy and occurrence reporting requirements are applicable to unexpected changes in ventilation system pressures (Ellis 1992 and WHC-CM-1-3).

\subsection{WASTE TANK LEAK DETECTION AND RESPONSE}

Cooling water additions are necessary to regulate the temperature of tank 241-C-106 and, thereby, maintain the integrity of the tank's concrete structure. In the event of a leak, the ability to continue to cool the waste sufficiently would become a primary concern. Sufficient waste shall be retrieved as soon as practical after a leak is identified, so that forced cooling will no longer be required. Depending on the location and severity of the leak, and if cooling water additions could not be controlled to prevent further leakage, additions would at least be controlled to minimize leakage to the soil column until the waste could be retrieved.

\subsubsection{Administrative Controls}

Administrative documents and procedures are in place to ensure that corrective responses take place both before and after any liquid-level readings violate the criteria in Section 3.4.2. The controlling documents and procedures are identified in Section 3.1.1. [Specific SST technical criteria limits and controls, including those for tank 241-C-106, are contained in the Waste Storage Tank Status and Leak Detection Criteria (Welty and Vermeuien 1991).]

If liquid-level monitoring systems are added or modified, this action plan will be revised to reflect any changes in configuration, criteria, and controls.

\subsubsection{Waste Tank Leak-Detection Criteria}

3.4.2.1 Waste Tank Liquid-Level Monitoring Criteria. Liquid-level criteria are specified in Waste Storage Tank Status and Leak Detection Criteria (Welty and Vermeulen 1991). The supernate level is controlled between 2.0 and $1.9 \mathrm{~m}$ (79 and $74.5 \mathrm{in}$. levels) to maintain a liquid layer above the solids surface, so as to keep the sludge wet and facilitate evaporative cooling. The surface level measurements are accurate to $\pm 0.6 \mathrm{~cm}( \pm 1 / 4 \mathrm{in}$., which is about $700 \mathrm{gal})$. The periodic behavior of the surface level is logged and manually analyzed for anomalies.

An experimental mathematical model has been developed to relate the surface-level readings versus time following water additions to the tank. Any departure from these prediction curves under steady-state conditions will result in increased surveillance and an engineering evaluation of the status of tank 241-C-106. 
Leak-detection criteria are no more than a $5.1 \mathrm{~cm}(2.0 \mathrm{in.})$ decrease in two weeks, or any increase of $5.1 \mathrm{~cm}(2.0 \mathrm{in.})$ from the baseline value. Furthermore, baseline changes for liquid-level decreases must not exceed decreases that are based on current psychometric data. New baselines must be within $1.3 \mathrm{~cm}(0.5 \mathrm{in.})$ of the current liquid level.

3.4.2.2 Dry-Well Monitoring Criteria. Dry-well radiation criteria are specified in Waste Storage Tank Status and Leak Detection Criteria (Welty and Vermeulen 1991). Action criteria for gamma monitoring require either (1) a doubling in radiation levels and an increase above 200 counts per second (c/s) for baseline values below $200 \mathrm{c} / \mathrm{s}$; or (2) a doubling of radiation levels above the baseline for baselines above $200 \mathrm{c} / \mathrm{s}$. Action criteria for neutron monitoring require either (1) a tripling in radiation levels for baseline values between 16 and $1,000 \mathrm{c} / \mathrm{s}$; or (2) a doubling of radiation levels above the baseline for baselines above $1,000 \mathrm{c} / \mathrm{s}$.

\subsubsection{Monitoring Frequencies}

3.4.3.1 Waste Tank Liquid-Level Monitoring Frequencies. Liquid levels are monitored within the tank farm facilities as specified in the Waste Storage Tank Status and Leak Detection Criteria (Welty and Vermeulen 1991). The levels in tank 241-C-106 are monitored on a weekly basis.

3.4.3.2 Dry-Well Monitoring Frequencies. Dry-well levels are monitored within the tank farm facilities as specified in the Waste Storage Tank Status and Leak Detection Criteria (Welty and Vermeulen 1991). Six dry wells are associated with tank 241-C-106. These wells are scanned at least every two weeks for gamma activity. Each well is scanned once per year for neutron activity.

\subsubsection{Reporting Requirements}

WHC discrepancy and occurrence reporting requirements are applicable to unexpected changes in waste tank liquid levels (EII is 1992 and WHC-CM-1-3).

Non-routine releases are reported to DOE and WHC environinental personnel in compliance with the Occurrence Reporting and Processing of Operations Information, MRP 5.14 (WHC-CM-1-3), and DOE Order 5000.3A. If a "reportable" release is confirmed per DOE Order 5000.3A, procedure requirements to not ify the National Response Center and Ecology are outlined in WHC-CM-7-5.

\subsection{Waste Tank Forced Ventilation Failure and Response}

If the forced ventilation system for tank 241-C-106 is not operational, then the temperature of the tank waste will start rising. During a period from January 25 through June 5, 1992, ventilation in tank 241-C-106 was not operational due to failed equipment. In this time the maximum temperature in the sludge increased from $161{ }^{\circ} \mathrm{F}$ to $198^{\circ} \mathrm{F}$ (Figure 3-1), and dome vapor space temperature increased from $84^{\circ} \mathrm{F}$ to $148^{\circ} \mathrm{F}$. No water additions were required during this time frame. 
SINGLE SHELL TANH $106-C$

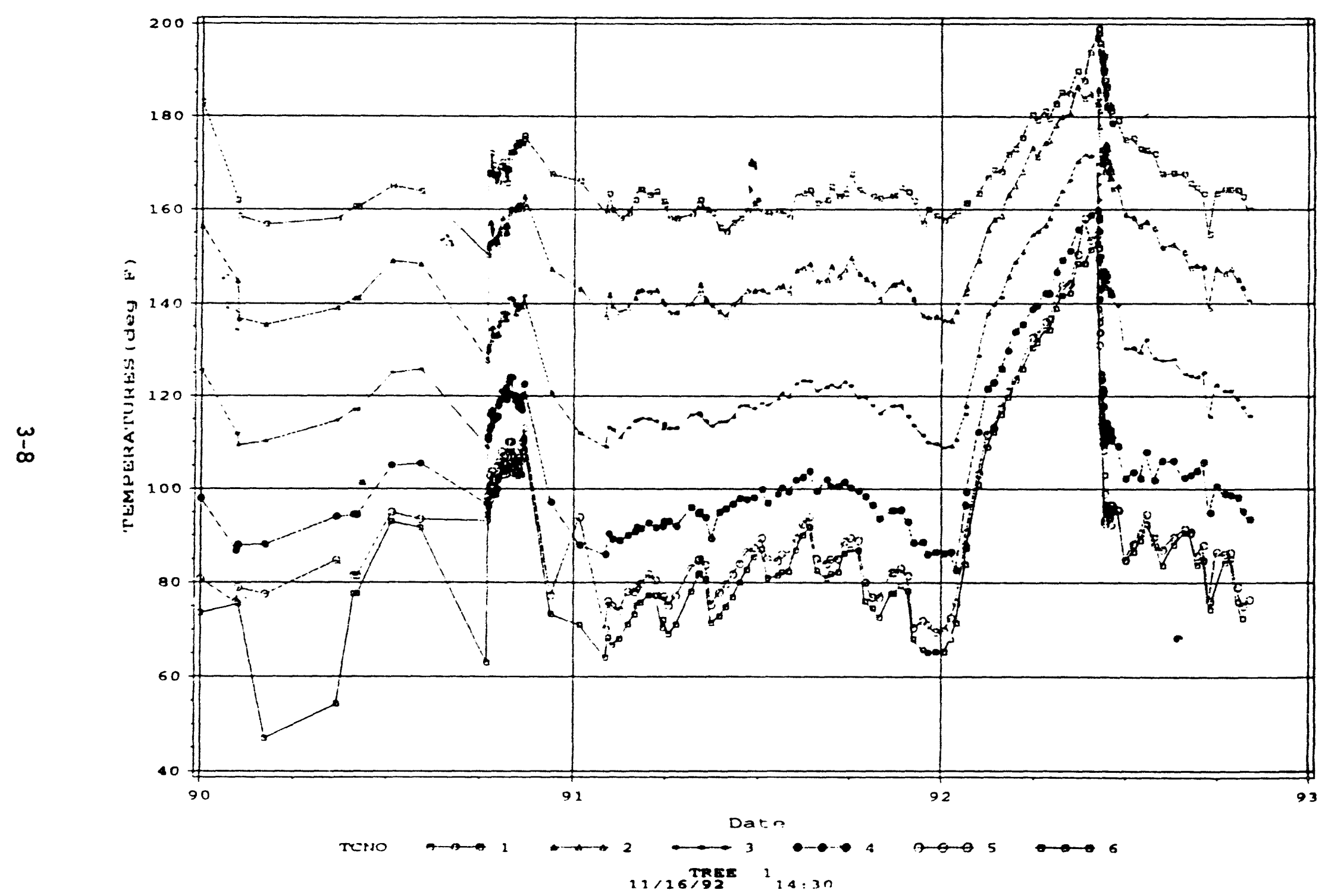

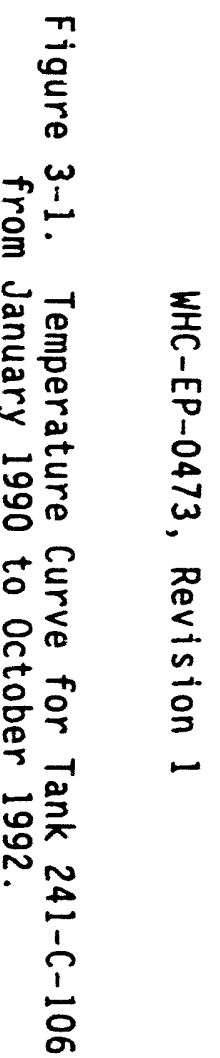




\subsubsection{Administrative Controls}

If the tank 241-C-106 ventilation system becomes nonoperational, the tank farm maintenance organization will submit a "corrective maintenance work package" within five working days. The monitoring frequency of temperature data will be increased to assure that temperature heat-up rates are within Operational Safety Requirements.

\subsubsection{Monitoring Requirements}

Thermocouple readings will be increased to a daily basis to assure that (1) temperature heat-up rates remain well below the $20^{\circ} \mathrm{F} /$ day; and (2) the maximum temperature in the waste is well below the Operational Safety Requirements limit of $350^{\circ} \mathrm{F}\left(300^{\circ} \mathrm{F}\right.$ is the Operational Safety Dccument limit). The Food Instrument Corporation data trend will continue to ba monitored on a weekly basis to assure that cooling water remains over the waste surface.

\subsubsection{Reporting Requirements}

A weekly report will be issued by Tank Farms Facility Operations to the managers of Tank Farms Operations and Waste Tank Safety Programs. This report will provide the status of forced cooling equipment repair, as well as thermocouple and Food Instrument Corporation data trends. 


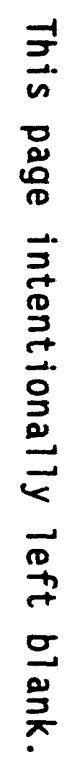




\subsection{RESPONSIBILITIES}

The Westinghouse Hanford Company Tank Waste Remediation System division is responsible for day-to-day tank farm operations (WHC-CM-5-5). The responsibilities associated with response to excessive temperature or pressure (or a release from any SST, including tank 241-C-106) are assigned as follows.

- Tank Farm Facility Operations shall be responsible for the safety of the facility and for routine monitoring of the waste tank. Initial screening of monitoring data also shall be performed by Tank Farm Facility Operations and Systems Engineering.

- Surveillance Analysis and Data Requisition receives temperature data and shall be responsible for (1) reviewing trending to predict when limits would be exceeded; (2) permanent logging (recordkeeping); and (3) reporting data. Additionally, Tank Farm Surveillance Analysis shall have the responsibility for reporting data anomalies and initiating response actions (E1lis 1992).

- Waste Tank Safety Assurance shall be responsible for providing independent safety review of all activities related to waste tank safety.

- The Manager of Tank Farms Facility Operations shall be responsible for conducting assessment activities and determining appropriate corrective actions.

- Corrective actions shall be defined by Engineering and Projects and implemented in the field by Facility Operations and other organizations as appropriate.

- Quality Assurance shall be responsible for verifying that activities affecting quality have been correctly performed.

- Waste Tank Safety Program shall be responsible for implementing safety-related programs. 
WHC-EP-0473, Revision 1

This page intentionally left blank. 
WHC-EP-0473, Revision 1

\subsection{CORRECTIVE ACTIONS}

The temperature of the sludge in tank 241-C-106 tanks normally fluctuates slightly because of changes in ambient conditions (temperature of surrounding soil, temperature and humidity of inlet air), and is expected to decline in proportion to the decay of the heat generating isotopes (primarily strontium). A consistent rise in temperature could be indicative of insufficient water present to sustain evaporative cooling. This condition, in turn, would be caused because either (1) an insufficient quantity of water was added to the tank; (2) a failed ventilation system (which provides the motive force for evaporative cooling); or (3) a leak occurring in the tank.

\subsection{TEMPERATURE INCREASES}

For uncontrolled temperature increases in tank 241-C-106 that exceed the monitoring criteria of Section 3.1, corrective actions will include one (or any combination) of the following:

- Addition of water (even if the tank is leaking) in minimum quantities to prevent temperature increases and restore temperature control [dry cooling methods have been calculated to be ineffective (Pauley and Torgerson 1987)].

- Adjustment to or modifications of the tank ventilation system.

- Accelerated retrieval of some (or all) sludge.

\subsection{LEAKING TANK}

Changes in tank liquid levels or dry-well radiation levels that violate surveillance criteria (Welty and Vermeulen 1991) could indicate a leak has occurred and normal conling water additions may not be adequate. Steps that will be taken are as follows.

\subsubsection{Immediate Actions}

The following actions will be taken in the event that tank $241-C-106$ is determined to leak. Actions should be completed within one month, and could be initiated during the leak investigation.

- Increase Surveillance - Surveillance frequencies will be increased for all parameters manually monitored for tank 241-C-106. Tank Farm Surveillance and Data Analys is will analyze the data and modify tank operations in accordance with WHC-IP-0842 (E11 is 1992).

- Reduce Supernatant Liquid - The liquid cover will be reduced from tank 241-C-106 by evaporation. The percent reduced will be determined by Engineering based on thermal models, previous operating data, and recommendations from Waste Tank Safety Programs. 
- Accelerate Removal of Waste Sludge - Engineering activities have been initiated to remove the waste from tank 106-C. The conditions for early retrieval on a non-emergency basis are discussed in an engineering study (Squires, et. al. 1991) and the Tank C-106 Early Retrieval Plan (Henderson 1993). Under emergency conditions, the early retrieval plan can be further accelerated depending on available resources and regulatory relief.

The early retrieval plan describes retrieval options, transfer lines, sluicing equipment, receipt tank options, tank space consideration, logic diagrams, regulatory requirements, safety documentation (etc.). Even on an non-emergency basis, the estimated schedule durations range from 29 to 52 months.

At this time, Westinghouse Hanford has no resources or plan to perform tasks earlier than the early retrieval plan. However, all available resources will be redirected to emergency retrieval in case of a leaking tank.

\subsubsection{Long-Term Actions}

After all necessary immediate actions have been performed, additional actions will be required to assess trends in the tank temperatures. These include the following:

- Monitor Soil Temperatures - A significant leak from tank 241-C-106 would be expected to raise soil temperatures by the liquid in the effluent plume. Soil temperatures will be monitored in the area of expected migration, along with dry well radiation scanning.

- Install Thermocouples - Additional thermocouples may be installed in tank 241-C-106 in locations determined by Engineering, if this is deemed necessary by Engineering and Waste Tank Safety Programs.

- Maximize Ventilation - Because tanks 241-C-105 and 241-C-106 share a common ventilation system, efforts to c001 241-C-106 could be impeded. The system valve from tank $241-\mathrm{C}-105$ will be reduced, as necessary, if so determined by Tank Farms Facility Operations. The process condensate drain from the vent system (which drains to 241-C-106) will then return only 241-C-106 liquid to tank 241-C-106.

- Photograph Tank Interior - When the liquid has been reduced, the tank interior will be photographed. Comparison of these photos with previous photos may help identify the leak location. If the leak location can be identified, and is above the sludge, a new liquid level high operating limit may be set below the leak line. The liquid cover may then be reestablished to maintain cooling. Normal operations would be resumed.

If no leak location can be pinpointed, further contingency actions would be required (see next bullet). 
- Retrieve the High-Heat Waste - Equipment will be installed and waste transfer systems constructed to allow retrieval and transfer of the waste to the DST system as soon as possible after a leak is detected. WHC staff will work closely with Washington State and the DOE to accelerate necessary approvals to support the retrieval activities.

- Install Surface Sprinkler - A sprinkler will be installed to keep the waste surface moist (Figure 5-1). The system will be fabricated from standard locally-available equipment to provide a spray capable of wetting $2 / 3$ to $3 / 4$ of the tank diameter. It is not desirable to spray the tank walls. The system will be operated on a timer. Tank Farm Engineering will provide the design and initial timing, and will modify the timing as operating experience is gained.

\subsection{VENTILATION SYSTEM ANOMALIES}

Abnormal ventilation system conditions (plugged or failed high efficiency particulate air filters, mechanical failure of the ventilation equipment, etc.) would be detected by anomalous ventilation duct pressures, and/or an increase in airborne radiation levels. The response to these conditions would be to restore the ventilation system to its normal operational condition. 
WHC-EP-0473, Revision 1

Figure 5-1. Sprinkler System Model.

\section{Sprinkler System}

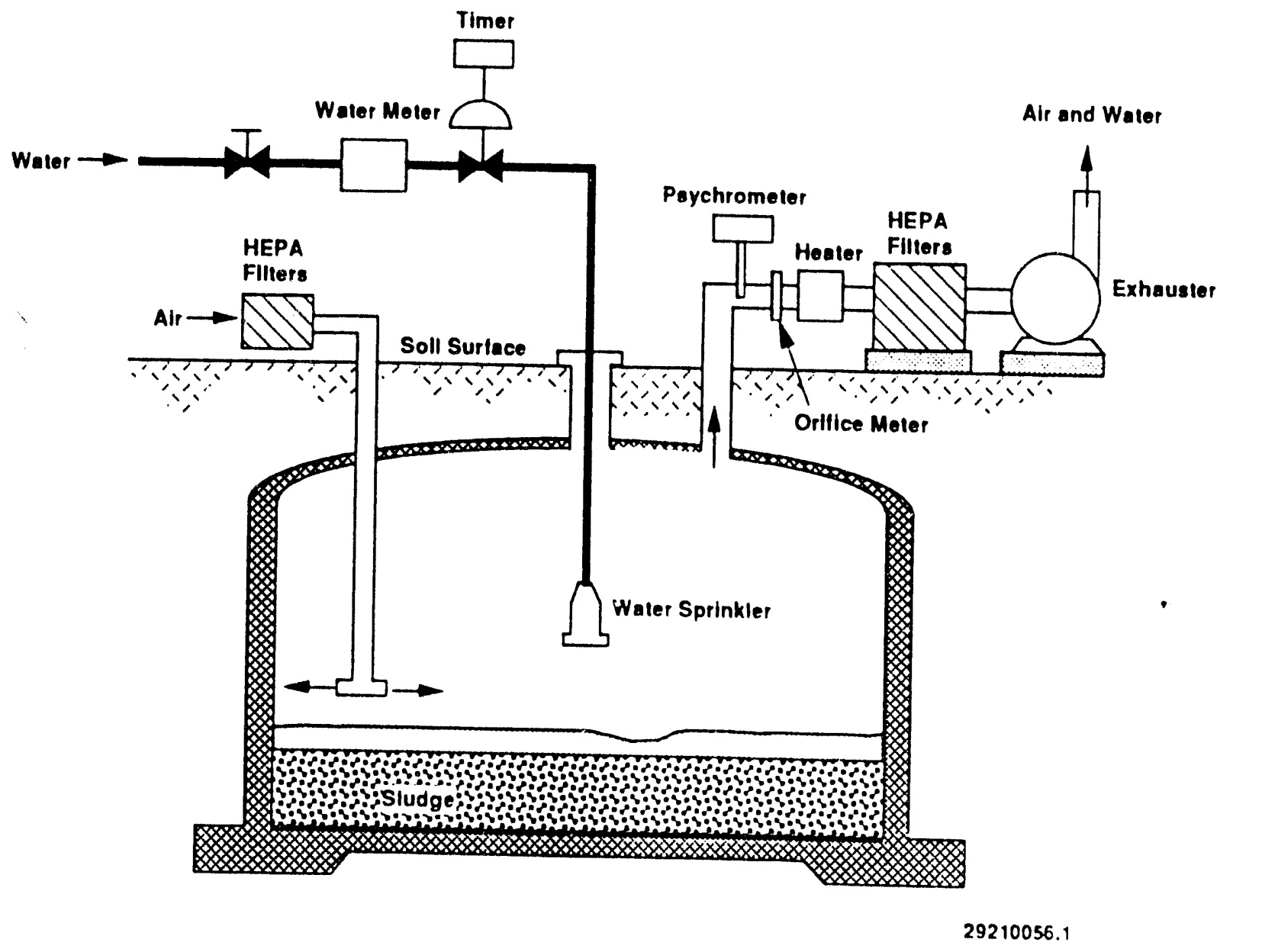




\subsection{REFERENCES}

Boyles, V. C., 1989, Safety Analysis Report - Stabilization of Single-Shell Waste Storage Tanks by Salt Well Jet Pumping, SD-WM-SAR-034, Rev. 0 , Westinghouse Hanford Company, Richland, Washington.

DOE, 1981, Environmental Protection, Safety and Health Protection Reporting Requirements, DOE Order 5484.1, U.S. Department of Energy, Washington, D.C.

DOE, 1986, Environmental Protection, Safety and Health Protection Standards, DOE Order 5480.1B, U.S. Department of Energy, Washington, D.C.

DOE, 1986, Safety Analysis and Review Systems, DOE Order 5481.1B, U.S. Department of Energy, Washington, D.C.

DOE, 1988, Radioactive Waste Management, DOE Order 5820.2A, U.S. Department of Energy, Washington, D.C.

DOE, 1989, General Design Criteria for DOE Facilities, DOE Order 6430.1A, U.S. Department of Energy, Washington, D.C.

DOE, 1991, Quality Assurance, DOE Order 5700.6C, U.S. Department of Energy, Washington, D.C.

DOE, 1992, Nuclear Safety Analysis Report, DOE Order 5480.23, U.S. Department of Energy, Washington, D.C.

DOE, 1993, Occurrence Reporting and Processing of Operations Information, DOE Order 5000.3B, U.S. Department of Energy, Washington, D.C.

DOE-RL, 1990, Radioactive Waste Management, DOE-RL Order 5820.2A, U.S. Department of Energy, Richland Field Office, Richland, Washington.

Ellis, S. H., 1992, Waste Tank Project Administration, WHC-IP-0842, 1992, Westinghouse Hanford Company, Richland, Washington.

Henderson, J. M., Letter report to N. L. Nichol, 1993, Tank 106-C Sluicing Letter Report 935041, January 15, 1993, Westinghouse Hanford Company, Richland, Washington.

Jimenez, R. F., 1991, Thermal Analysis of Tanks 241-C-105, 106 Using TAP-A as the Thermal Analysis Code, WHC-SD-WM-ER-075, Rev. 0, Westinghouse Hanford Company, Richland, Washington.

Marsh, D. A., 1991, Tank Farm Stabilization Plan for Emergency Response, WHC-SD-PRP-TI-001, Rev. 0, Westinghouse Hanford Company, Richland, Washington.

Pauley, T. R. and M. M. Torgerson, 1987, Tanks 105-C and 105-C Stabilization Study, RHO-RE-EV-97, Rockwell Hanford Operations, Richland, Washington. 
"Safety Measures for Waste Tanks at Hanford Nuclear Reservation," Section 3137 of National Defense Authorization Act for Fiscal Year 1991, Public Law 101-510, November 5, 1990.

Smith, D. A., 1986a, Hazard Identification and Evaluation for Nonstabilized Single-Shell Tanks, SD-WM-SAR-022, Rev. 0, Rockwell Hanford Operations, Richl and, Washington.

Smith, D. A., 1986b, Single-Shell Tank Isolation Safety Analysis Report, SD-WM-SAR-006, Rev. 2, Rockwe 11 Hanford Operations, Richland, Washington.

Squires, K. G., G. A. Barnes, T. R. Benegas, R. R. Cruz, J. M. Henderson, E. L. Kunkler, J. D. Ludowise, and S. W. Shaw, 1991, Engineering Study for Partial Retrieval of Tank 241-C-106, Westinghouse Hanford Company, Richland, Washington.

Welty, R. K., 1988, Waste Storage Tank Status and Leak Detection Criteria, WHC-SD-TI-356, Westinghouse Hanford Company, Richland, Washington.

Welty, R. K. and N. J. Vermeulen, 1991, Waste Storage Tank Status and Leak Detection Criteria, WHC-SD-WM-TI-357, Rev. 1G, Westinghouse Hanford Company, Richland, Washington.

WHC, 1990, "Interim Tank Farms Occurrence Reporting and Processing of Operations Information," Tank Farms, Grout, and Solid Waste Management Administration Manua 7, WHC-CM-5-7, Section 1.22, Rev. 0, Westinghouse Hanford Company, Richland, Washington.

WHC, 1992a, Operating Specifications for Single-Shell Waste Storage Tanks, OSD-T-151-00013, Rev. D-1, Westinghouse Hanford Company, Richland, Washington.

WHC, 1992b, Operating Specifications for Watch List Tanks, OSD-T-151-00030, Rev. A-1, Westinghouse Hanford Company, Richland, Washington.

WHC-CM-1-3, Management Requirements and Procedures, Westinghouse Hanford Company, Richland, Washington.

WHC-CM-4-1, Westinghouse Hanford Company Emergency Plan, Westinghouse Hanford Company, Richland, Washington.

WHC-CM-4-10, Radiation Protection, Westinghouse Hanford Company, Richland, Washington.

WHC-CM-4-43, Westinghouse Hanford Company Emergency Management Procedures, Westinghouse Hanford Company, Richland, Washington.

WHC-CM-5-5, Operations - General Administration, "Waste Tank Anomaly Analysis and Reporting," Procedure GA-2.18, Rev. 0, Westinghouse Hanford Company, Richland, Washington.

WHC-CM-7-5, Environmental Compliance, Westinghouse Hanford Company, Richland, Washington. 
WHC-EP-0473, Revision 1

Wilson, G. R. and I. E. Reep, 1991, A Plan to Implement Remediation of Safety Issues at the Hanford Site, WHC-EP-0422, Westinghouse Hanford Company, Richland, Washington. 
WHC-EP-0473, Revision 1

This page intentionally left blank. 


\section{DISTRIBUTION}

\section{Number of Copies}

OFFSITE

5

U.S. Department of Energy-Headquarters

EM-36, Trevion II

Washington D.C. 20585

J. C. Tseng

ONSITE

14

U.S. Department of Energy, Field office. Richland

G. E. Bishop

R2-62

G. J. Bracken

A4-02

R. F. Christensen

A4-02

R. E. Gerton

A4-02

R. G. Harwood (6)

A4-02

A. D. Toth

S. H. Wiseness

J. K. Yerxa

R2-62

A5- 15

Public Reading Room

A5-15

Al -65

Pacific Northwest Laboratory

D. M. Strachan

$K 2-38$

Technical Files

$\mathrm{K} 1-11$

Westinghouse Hanford Company

B. A. Austin

B2 -35

H. Babad

R2 -08

D. C. Board

S1-57

V. C. Boyles

G. M. Christensen

C. Defigh-Price (2)

R1-49

H2-41

L. P. Diediker

R2-31

G. L. Dunford

T1 -30

C. J. Forbes

R1-51

J. C. Fulton

$\mathrm{R} 1-08$

K. A. Gasper

S. D. Godfrey

J. M. Grigsby

$\mathrm{R} 2-31$

R2 -08

R1-51

D. G. Hamrick

H5-32

B. M. Hanlon

R1-51

H. D. Harmon

$\mathrm{R} 1-80$

J. M. Henderson

R2-52

L. L. Humphreys 
WHC-EP-0473, Revision 1

DISTRIBUTION (continued)

Number of Copies

ONSITE

West inghouse Hanford Company (cont inued)

M. N. Is I am

R3-08

D. B. Pabst

$B 2-35$

M. A. Payne

C. C. Pitkoff

R. E. Raymond

D. C. Richardson

T. B. Veneziano

O. S. Wang

D. D. Wiggins

D. D. Wodrich

Central Files

Document Processing and Distribution (2)

Information Release Administration

R2 -50

$R 1-49$

$R 1-80$

R2 -31

$\mathrm{B} 2-35$

R2-31

$R 1-49$

R2-23

L8-04

L8-15

TFIC

R1-08

RI-28 


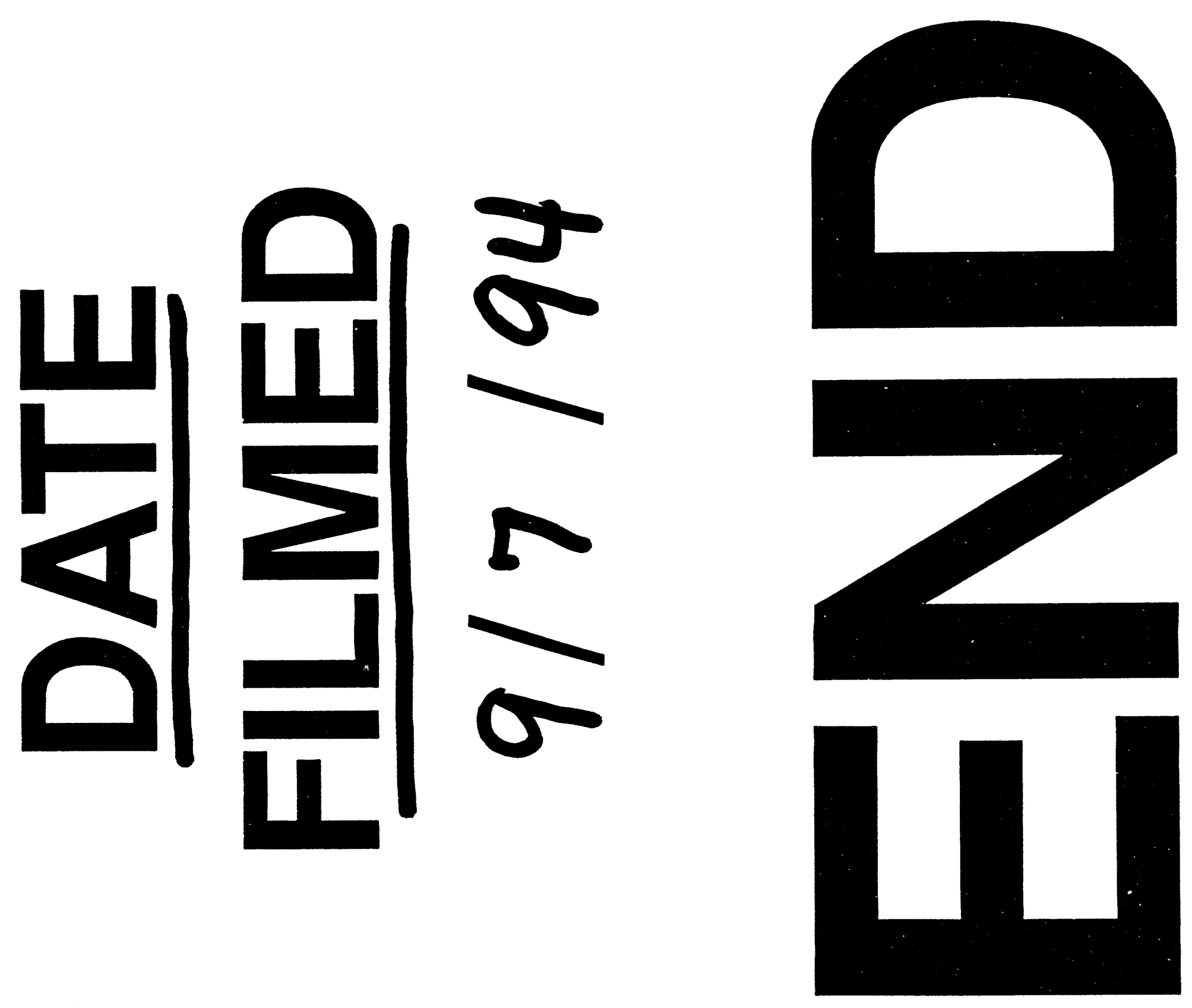




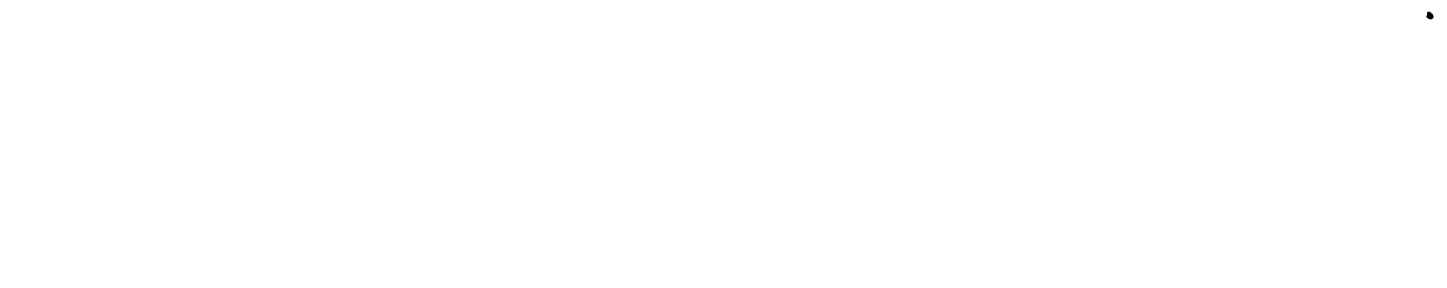

